\title{
Market Efficiency and Organizational Corruption: Study on the Impact on Shareholder Value
}

\author{
Renata Crosara Miari ${ }^{\dagger}$ \\ FUMEC University
}

\author{
José Marcos Carvalho de Mesquita ${ }^{\Omega}$ \\ FUMEC University
}

\author{
Daniel Jardim Pardini ${ }^{¥}$ \\ FUMEC University
}

\begin{abstract}
With this study, we evaluated the influence of disclosure of the involvement of organizations in corruption on creating value for shareholders. We chosen four companies that had their names linked to allegations of corruption in the past 10 years. An event study was used to verify if relevant information tends to be immediately reflected in stock prices. We selected 28 events for analysis and we observed negative and positive variations of the securities in relation to the market, in the days before the disclosure, as in most of the 20 days after publication. However, in cumulative terms, there was a rise in prices over time, returning to levels near those observed before advertising the event. The results indicate that the market did not behave efficiently in this analyzed period.
\end{abstract}

Key words: Corruption. Value creation. Stock market.

*Author for correspondence:

${ }^{\dagger}$. Master in Administration Instituition: Fumec University Adress: Avenida Afonso Pena, $3880,1^{\circ}$ andar Bairro Cruzeiro, Belo Horizonte - MG Brazil - CEP 30.130-009

Email: crosara3@gmail.com ou renata.miari@hotmail.com

\author{
$\Omega$. Doctor in Administration \\ Instituition: Fumec \\ University \\ Adress: Avenida Afonso \\ Pena, $3880,1^{\circ}$ andar Bairro \\ Cruzeiro, , Belo Horizonte \\ - MG - Brazil \\ CEP 30.130-009 \\ Email: \\ jose.mesquita@fumec.br
}

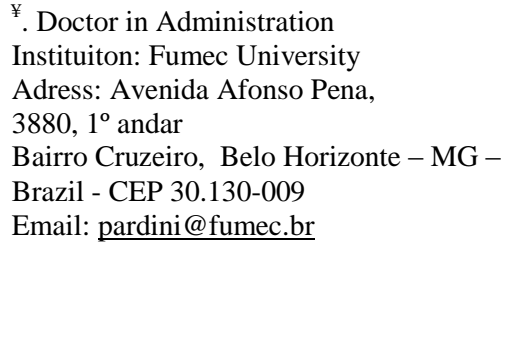
Instituiton: Fumec University Adress: Avenida Afonso Pena, $3880,1^{\circ}$ andar Brazil - CEP 30.130-009 Email: pardini@fumec.br

Note from the Editor: The article was accepted by Emerson Mainardes. 


\section{INTRODUCTION}

llicit actions performed by corrupt agents have a negative effect on organizations.

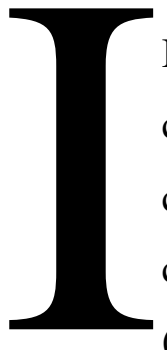

Businesses of all types may experience huge losses due to corruption and the spread of corrupt acts affects negatively the financial results and corroborates to deteriorate corporate image. Corruption is responsible for making less money in almost every country and it involves a capital deviation around US\$ 1 trillion per year worldwide (ZINNBAUER, 2012). It is restricted not only in large economies, but also in small economies. Systemic and persistent corruption appears to be common reality of organizational life in both developing and developed countries (MISANGYI et al., 2008; AIDT, 2003). Corruption does not just happen in the capitalist system, but it turns out to be also a problem in socialist and communist countries. It is not even an accomplishment of modernity, because there are numerous reports of corruption in the human civilization history. More than two thousand years ago, Greek philosopher Aristotle (384-322 BC) mentioned that “corruption was the republic evil" (CRICK, 2002).

The literature holds some research on corruption with economic, behavioral and management focuses. It has also been studied by various disciplines such as theology, psychology, sociology, economics, law, anthropology and political science. The subject that encompasses the economic dimension seeks to understand the effects of corruption on development and growth of economies (MAURO, 1995; SCHWARTZMAN, 2008). In the field of theology, we can emphasize Folarin (2010), which analyzes the high levels of corruption in various public offices in Nigeria in the light of the Gospel of Luke (12:13-21), and dealing with human greed.

In the field of ethics, Comparato (2006) presents a detailed study addressing the law, morals and religion in the modern world. He points out the capitalist system as the greatest evil of mankind at the beginning of this millennium in ethical terms. Anand, Ashforth and Joshi (2005) studied the corrupt behavior in organizations and concluded that, generally, this corrupt behavior tends to become acceptable and constant in certain organizations. The authors argue that this phenomenon can be explained in part by the principle of rationalization. Individuals draw mental strategies to make their corrupt acts justified for themselves and those around them.

Although business schools have studied corruption on both levels, individual and organization, only the most recent studies focus on corruption in two dimensions: when an 
individual or group of individuals are the beneficiaries of corruption, and when the corrupt conduct is undertaken by one or more individuals to benefit the organization.

Pinto et al (2008) suggest that corruption in organizations can be manifested by two phenomena: the organization of corrupt individuals (OCI), in which members act corruptly for their own benefit, and corrupt organization (CO) where a group so corrupt acts collectively for the benefit of the organization. In both arrangements, the organization is the central unit, ie, one that brings together individuals around objectives driven by misconduct. To Ermann and Lundman (2002), the misconduct in large organizations, in general, are conducted, whether directly or indirectly, by organizational elites. Other perspectives found in literature on corruption include ethical decision-making (JONES, 1991), government, political and legislative corruption (SCHLEIFER; VISHNY, 1993; NICE, 1986; JAIN, 2001); normalization of corruption (ASHFORTH; ANAND, 2003) and social networks (NIELSEN, 2003). While management scholars have examined corruption at those different perspectives, the financial level studies are until underexplored.

In recent years a number of corrupt acts in Brazilian public and private sectors has been systematically monitored and reported by various media. "Though delayed," said Lima (2008, p. 481), it is a process of professionalization of Brazilian journalism and the consequent emergence of investigative journalism. According Enrique Peruzzotti, quoted by Lima (2008), "the media scandals represent the action of the more salient social control in terms of striving corruption" (LIMA, 2008, p. 481).

Given the above, we sought to answer the following research question: What are the effects of organizational corruption on the shareholders' value? Besides this introduction, in the next topic, we dealt with the concept of corruption and its economic and social implications. The third part of the paper presents the methodology and results. Finally, the fourth part presents the conclusions of this work.

\section{LITERATURE REVIEW}

\subsection{CORRUPTION - CONCEPT AND ECONOMIC AND SOCIAL IMPLICATIONS}

The word corruption derives from Latin term corruptionis, which is the conjugation of two Latin terms cum and rumpo (verb to break). It means a complete break; break the whole; break it completely. Corruption also expresses disruption or deviation of a moral code or social behavior. The word also carries a strong negative sense that qualifies conditions and actions associated with degeneration, perversion and bribery. 
Machiavelli, one of the first thinkers to contextualize the concept of organization, deals with the social origins of corrupt actions in organizations: "Corruption refers primarily to the customs of the people that once corrupted, prevent good ordinances (good institutions) to produce more good effects and laws are no more effective" (MACHIAVELLI, quoted ADVERSE, 2008, p. 41).

Klitgaard (1991) presents an analytical perspective of corrupt action focused on three propositions. Firstly, we have to recognize that corruption is a multidimensional phenomenon that can take place at organizations of any kind. It is manifested in both external and internal contexts. Second, we also should consider corruption as the action of a group of people whose ethical standard does not fit in the moral standard set by society. The third assumption refers to the fact that people have free will and act according to their value orientations rather than any established legal standard.

Several authors highlight the difficulties in defining corruption, since the perception, or tolerance, regarding the subject matter varies from country to country, from culture to culture and even between different social groups. Following the definition offered by Borini and Grisi (2007, p. 1):

\footnotetext{
It was the Heidenheimer (1970) thesis that brought up the importance of social relations in land that is a corrupt practice or not. Heidenheimer suggested three types of corruption. The "black corruption" when law and social norm coincide, ie, the law punishes and society believes that that act should be punished and will [...]. The "white corruption" that is the extreme opposite of the "black corruption", [...]. And the "gray corruption" when social actors evaluate particular behavior in a controversial manner (BORIN; GRISE, 2007, p. 1).
}

Heidenheimer (2002) adds to these concepts the difficulty of demarcating the borders between the three types of corruption, as these may vary according to the community, those involved in the acts and the acts harmed. In the same direction, Martins (2008, p. 23) argues that corruption is installed in places where predominate the legal and institutional inefficiency.

According to Comparato (2006, p. 583), the modern world were characterized by "progressive disconnection of the original regulatory system - which included moral, law and religion" and the best example of this is politics. The author cites "Machiavelli and Hobbes," which, each in his own way, defended the thesis that political action should free itself from "traditional ethical constraints." Following the same idea, the founders of economic science have proposed a "radical separation between the sphere of the state and civil society." This is 
because it was believed that the economy would be governed by natural laws, for which governments should complete obedience.

To stop these movements and restore ethical principles, Comparato (2006) explains the emergence of human rights movement from the late seventeenth century, first in Europe and then throughout the world. As described by the author "it is a progressive movement of human rights, and combating abuse of power, not only political but also economic and religious" (COMPARATO, 2006, p. 583). In the same direction Schwartzman (2008, p. 5), states that the concept of corruption is most widely associated with the "misuse of public position to obtain private gain".

However, it is necessary to extend this concept, since this study aims to address corruption in the private sphere. Schwartzman $(2008$, p. 6) revealed that the widespread practice of corruption affects the economic intentions of a nation and that "the existence of corrupt practices in one country helps or hinders economic activity and thus the creation of wealth and economic development". Mauro (1995) is a pioneer in the studies on the effects of corruption on economic growth. Through a survey conducted in seventy countries, $\mathrm{He}$ concluded that the countries' economic growth is directly affected by corruption, since institutional inefficiency reduces investments in those localities where prevail the corrupt acts.

A deeper understanding on corruption offers several ways of seeing it in organizations, including micro, macro, wide, long and deep views (ASHFORTH et al., 2008). The micro perspective focuses on understanding how organizational environments become corrupt, how individuals are linked together in corrupt networks. Scholars' operating within the macro view go beyond individual organizations and attempt to understand why entire industries harbor corruption. They are interested in examining corruption in industrial sectors or at national levels. In the wide view investigations on corruption considerate both individuals and institutions; this perspective encourages us to look at the whole system to comprehend the reach of corruption's import. Longitudinal studies about corruption on organizations (regulations and law propositions) are the focus of the long view, the goal is to look corruption over time. The deep view would recognize that corruption is a dynamic disease that can evolve in complex ways (ASHFORTH et. al., 2008).

Corruption is also understood as a sudden or gradual act contrary to the norms and current values. It needs a corrupting agent acting alone or in groups in order to achieve benefits for one or themselves. The corruptor has a seductive behavior seeking fraudulent and solidarity advantage. Corrupts aim to break the rules and moral obligations in the financial, 
political and judicial areas in which they operate. The desired benefits could have material nature, especially financial advantages and other kinds of benefits such as power, prestige, promotion and strategic positions in a company.

One of the organizational corruption causes is associated to the search for incomes or rent-seekings that are defined as being the competence of companies, executives or interest groups who organize themselves in order to get privileges, income and political favors. Although rent-seeking is not the only source of corruption and entrepreneurs are not the only corrupts in the corporate arena, this device draws attention because of their recurrences and interactions with the public sector.

Identifying and describing corruption practices seem to be the most satisfactory alternative to open up for a deeper understanding about the complexity of corrupt behaviors. Olivier de Sardan (1999) uses the term 'corruption complex' to include practices beyond corruption in the strict sense of the word; for instance nepotism, abuse of power, embezzlement and various forms of misappropriation, influence peddling, prevarication, insider trading and abuse of public purse.

Fraud and money laundering are also two other corrupt practices standing out in the literature (PARDINI et. al. 2011). Among corrupt actions taking place in the financial system, fraud is the most studied one and it also produces great amounts of financial losses. Fraud is a big issue, but its detection will be increasingly more difficult due to the sophistication of technology facilities. Money laundering is a practice that causes large losses to organizations, as well. The origin of the term dates back to American mafia organizations, which, in the 1920s, "invested" money on it. They got through criminal activities at laundries and car washes. This criminal practice aims to dissimulate or hide the illicit origin of financial assets or patrimony through a maneuver that will legitimate the licit origin or at least making the illicit origin be more difficult either to demonstrate or prove.

More corrupt practices are considered in the literature (PARDINI; MACHADO; COSTA, 2013):

1. Not accounted cashes - accumulating funds not official accounted.

2. Active bribery - offering to an individual, any undue advantage expecting back illicit benefits.

3. Passive corruption - soliciting or receiving, for oneself or another, an undue advantage. 
4. Influence peddling - asking, demanding, collecting or getting for oneself or others, advantages and benefit promises. In other words, using an authority to get favours or special treatments, most of the time, expecting back payment for that.

5. Gang of criminals - people get together having criminal objectives.

6. Management reckless - managing third party funds in a risky way.

7. Administrative law - sponsoring the public worker directly or indirectly.

8. Concussion - requiring, for oneself or others, directly or indirectly, any undue advantage.

\subsection{MECHANISMS OF CONTROL AND MEASUREMENT OF CORRUPTION}

The State and its institutions are primarily responsible for striving against the illicit public corruption (ROSA, 2004), as well as private corruption. The State is supposed to contend corruption through clear legislation, a police force and an acting justice efficiently and effectively.

Among the mechanisms of external control of corruption should be noted the important role of International Transparency (IT) and its studies to measure levels of corruption worldwide. Importance should also be given to the professionalization of the media and press freedom, openly exposing corrupt acts, making public what until recently was unknown to a large extent of the population.

However, contending corruption in organizations still rely on internal mechanisms that are effective and able to establish a new organizational culture. In recent years business schools have been conducting studies on this issue to the understanding of this growing phenomenon and certainly soon will arise suggestions for procedures that effectively work together to mitigate the problem.

Misangyi, Weaver, and Elms (2008) argue that prevention is the best instrument to control corruption. The researchers argue that corrupt organizations must change the "institutional logic" to strive against corruption. Among the tools that help decrease the intentions of corrupt practices lies the ethics code. Considered a guidance document of organizational behavior, the ethics code serves as a management tool that aims to inform employees what is the acceptable behavior in the organization environment. Anand et al. (2005) argue that the adoption of the code is a positive development, but not enough. The authors argue that organizations can sometimes adopt the code as a badge of morality. 
Nowadays the strive against corruption requires joint, multidisciplinary and informed strategies, since it is not just between two individuals of corruption (passive and active). The increasing complexity of the phenomenon makes itself felt in the nature of the actors, the type of exchanges, the contexts in which they occur and the sophistication of the mechanisms of transaction (SOUSA, 2008, p. 26). The author says that each day is necessary an equally or more sophisticated intervene in identifying and combating corruption. It is a worldwide phenomenon and not unique to the Brazilian reality.

The recent financial scandals involving companies like Enron, WorldCom, Tyco, HealthSouth, GlobalCrossing, Lucent and Parmalat, the failure of the 4th largest U.S. bank, Lehman Brothers, and the suspicions that fell on giants of the independent audit as the Ernst and Young and the bankruptcy Arthur Andersen, have shaken the credibility of the U.S. economy and other economies considered solid so far. The financial crisis has awakened the authorities to the need for a tighter control over private companies and financial institutions, and especially on those who trade securities on the stock market. As a result, the corporate governance practices have become widely recognized.

The Corporate Governance wants to take care of the various conflicts arising from the dissociation between ownership and management, which arose as a consequence of increasing big corporations, boosting capital dispersion control (JENSEN; MECKLING, 1976). The phenomenon of dispersion of capital transferred to the organizations' managers responsibility for important decisions, and not always, these decisions consider the interests of shareholders. Termed as the agency conflict, it arises from imperfect control of shareholders on their managers.

From this desire to establish good governance practices, result legal instruments and regulatory frameworks aimed at protecting the shareholders rights and, consequently, the greater protection of their interests, which should be the creation of value. A study conducted by Garcia, Sato and Caselani (2004) examined Brazilian companies that have launched securities overseas in recent years, the American Depositary Receipts (ADRs). The study concluded that the Brazilian companies had a higher performance in their prices in the Brazilian market "at time of event registration is granted ADR", which implies its commitment to "higher standards of disclosure" and confirmed by the "valuation of companies" (GARCIA et al., 2004, p. 10).

In 2000, São Paulo Stock Exchange (Bolsa de Valores de São Paulo - BOVESPA) launched a new market segment called New Market. Companies participating in this segment 
are committed to follow a set of rules that expand the shareholders rights, adopt a policy of disclosure similar to more developed markets and are committed to issue only common shares. Participate in the New Market provides the companies a fairer price for their assets (SANTANA, 2002, p. 5). Already the Securities and Exchange Commission (COMISSÃO DE VALORES MOBILIÁRIOS - CVM), despite having a key role in controlling the activities of publicly traded Brazilian companies, operates in a manner much more reactive than preventive practices in relation to corporate corruption.

\subsection{THE VALUE CREATION FOR SHAREHOLDERS}

Pereira and Eid Junior (2002) presented a study to relate the value creation and stock returns, and for that addressed a variety of methods to measure and monitor the value creation. Among the mentioned models in the study it is necessary to highlight those that are most commonly used today as: Free Cash Flow (FCF), Economic Value Added (EVA) and Cash Value Added (CVA).

Similar to the model of dividends, which values the company in terms of expected future dividends, the FCF model is based on the present value of expected free cash flows of a particular investment and discounted weighted average cost of capital. Therefore:

$$
\text { Companyvalue }_{F C F}=\frac{F C F_{1}}{\left(1+r_{a}\right)^{1}}+\frac{F C F_{2}}{\left(1+r_{a}\right)^{2}}+\ldots+\frac{F C F_{\infty}}{\left(1+r_{a}\right)^{\infty}}
$$

Where: $\mathrm{FCF}_{\mathrm{t}}$ is the free cash flow expected at the end of period $t$, and $r_{a}$ is the weighted average cost of capital of the company.

The FCF model was adopted in many organizations because of its general nature. However, for a better assessment of the value of the company it is necessary to apply more sophisticated models and more comprehensive calculation of the estimated return. Among these models, Mota and Oliveira (2004) conducted a study in order to compare the performance of EVA and CVA models. The authors developed a work based on the results of 38 large non-financial companies, as disclosed in the first quarter of 2004. The results of EVA and CVA were calculated and compared. The authors concluded that the CVA is better in representing the "operating performance of the business, while the EVA contains serious distortions generated by the asset depreciation and any decisions that lead to interruption of value-creating investment" (MOTA; OLIVEIRA, 2004, p. 15).

Pereira Junior and Eid (2002, p. 14) conclude that "if managers base their initiatives on goals that generate results above the cost of capital, the company is creating value, and this 
will be translated into stock prices, which are expected to rise to reflect the new economic situation of the business". In this sense, we adopt stock price as representing shareholders' value.

It is important to highlight that the Finance theory has been studying for several years the relationship between ethics in organizations and its stock price. Gitman (1997) compares the effects of the implementation of a proactive ethics program in organizations in order to strengthen corporate values and concludes:

An ethics program can produce many positive benefits: reduce potential litigation
and prosecution costs, maintain the positive image of the company, strengthen the
confidence of shareholders and gain the loyalty, commitment and respect of all the
constituents of the company. It is expected that such acts, to maintain and strengthen
cash flow and reduce the perceived risk [...] positively affect the price of the
company's action. (Gitman, 1997, p. 24)

Finally, in a more comprehensive way, it's important to mention Damodaran (1997) when he associates generation of value added and the stock price:

\begin{abstract}
When companies make good investment decisions, they add value; this value can be measured by the net present value obtained by the project. Most commonly, the quality of companies' projects is reflected in the profit multiplier expected by market to be paid for the shares of this company (DAMODARAN, 1997, p. 670).
\end{abstract}

\title{
3 METHODOLOGY
}

We conducted a descriptive research, with quantitative approach, as suggested by Collis and Hussey (2005) and Hair Jr et al (2005), through the analysis of secondary data on the Brazilian stock market. We adopted the event study because it was the method that best met the objectives of the study, linking specific events involving the performance of securities in the stock market. To support the choice of event study methodology, we can highlight a similar study conducted by Davidson III and Worrell (1988), which was based on this methodology to measure the effects of allegations of wrongdoing, published by The Wall Street Journal on the actions of U.S. companies. They selected 117 large U.S. corporations, which were caught committing some kind of irregularity, such as tax evasion, illegal political contributions, procurement fraud, violation of antitrust law, tax evasion, paying bribes, among other crimes (DAVIDSON III; WORREL, 1988, p. 196). Likewise, it is worth mentioning Camargos and Barbosa (2003b) who conducted a survey of the literature on event studies in Brazil, relating events studies held in the capital markets of Brazil between 1988 and 2001.

\subsection{EVENT STUDY}

Mackinlay (1997) points out that the event study has become an important corporate management tool, as it has been widely used in Accounting and Finance to measure the 
effects of economic events on the companies' assets. The author cites examples of applications of event studies, as the assessment of mergers and acquisitions, announcements of results, capture new sources of financing (debt capital or equity), announcements of macroeconomic variables, among others.

The model can also be used to measure effects on business due to changes in legislation, economic or regulatory environment. In the field of law, the event study can also be used to measure damage to property of others, when resulting from a specific event (MACKINLEY, 1997, p. 13).

The event study is a model to calculate and compare the observed return of the shares of companies traded on stock exchanges, with the expected return. The expected return serves as a comparative basis, because it is a return calculated in order to determine what would be the most likely behavior of the shares, if the allegations (events) had not occurred. By comparing the observed return and the expected return, we seek to determine whether abnormal returns occurred during the study period. When there is evidence that significant abnormalities occurred during the study period, one can conclude that the disclosures were relevant and affected the stock price.

Camargos and Barbosa (2006, p. 45) state that the event study methodology is used more to "assess the semi-strong form" and "whose tests seek to measure the speed of adjustment of stock prices around a specific date when there were disclosure of relevant information". The authors recommend that the study is set to a "zero date", or the date of dissemination of news (the event). This date should be established based on the first dissemination of market information about the event under study. The "zero date" or date of the event, is considered the date of publication of the relevant news.

Based on the date zero, Camargos and Barbosa (2006) suggest the establishment of the event window with 40 trading days, 20 days before and 20 days after the event; within the estimation window of -111 to -20 days should be calculated the coefficients alpha and beta of traded securities, which form the basis for calculating the expected return of the shares in the event window. This is what recommends the market model used in this study, which relates linearly the return of any action and market return (MACKINLAY, 1997, p. 18).

We opted for risk-adjusted returns and market model, based on the advantages presented below (CAMARGOS; BARBOSA, 2003b, p. 9):

1. This is the model most used in Brazil and the United States because of its simplicity; 
2. Presents a performance similar to higher end models like the CAPM (Capital Asset Pricing Model) itself;

3. And finally, the choice of the market model "does not involve altering the results and conclusions" of the study.

The event study formulates a comparison between observed ex post returns of stocks and an expected return (normal), calculated using the market model. Camargos and Barbosa (2003b) define normal return as the expected return without the condition that the event occurs, while the abnormal return is defined as the ex post observed return of a security minus the normal return of the firm in the event window. Initially we calculated the daily ex post market returns (based on index IBOVESPA) and the returns of common and preferred shares directly. Thus, the daily returns (r) were calculated using the following formula:

$$
r=\frac{P_{t}}{P_{t-1}}-1
$$

Where: $\mathrm{r}$ is the daily return rate and $\mathrm{P}_{\mathrm{t}}$ and $\mathrm{Pt}-1$ are stock prices in period $\mathrm{t}$ and in period $\mathrm{t}$ 1 , respectively.

Based on the calculated daily returns, we applied statistical regression to the results included in the estimation window (-111 to -21$)$. The period were selected in order to estimate the event's alpha and beta coefficients outside the window, as suggested by Campbell, Lo and Mackinlay (1997), so there is no interference in the event prices and, consequently, the determination of the coefficients.

Armed with the observed daily returns of the market $(\mathrm{Rm})$, we used the following formula to calculate the normal returns:

$$
E\left(R_{i t}\right)=\alpha_{i}+\beta_{i} E\left(R_{m}\right)
$$

where: $R_{i t}=$ observed return of title $i$ in period $t, E\left(R_{i t}\right)=$ expected normal return, $R_{m}=$ the market return observed at time t; $\alpha_{\mathrm{i}}$ and $\beta_{\mathrm{i}}=$ OLS (Ordinary Least Squares Coefficients).

Since the research objective was to verify the presence of abnormal returns within the event window, we used the following formula for calculating abnormal returns $\left(\mathrm{AR}_{\mathrm{it}}\right)$ :

$$
A R_{i t}=R_{i t}-E\left(R_{i t}\right)
$$

where: $A R_{i t}$ is the abnormal return to be observed, and and $R_{i t}$ and $E\left(R_{i t}\right)$ is the observed return and expected return, respectively. 
Camargos and Barbosa (2003b, p. 6) present in their study the need to calculate the cumulative abnormal return (CAR), in the event window based on the following formula:

$$
\operatorname{CAR}\left(t_{1}, t_{2}\right)=\sum_{t=t_{1}}^{t_{2}} A R_{i t}
$$

According to the authors, this is justified because "the market reaction can spread within days" to the event under study.

Calculated the cumulative abnormal returns $(\mathrm{CAR}-20,+20)$ proceeded to calculate the average daily abnormal returns (AR-20, +20) and cumulative abnormal returns (CAR-20, +20 ) for all stock prices within the event window in order to identify potential abnormalities in the 20 days before and after those events reported $(-20$ to +20$)$. Based on the average results obtained, we calculated the standard deviation of cumulative abnormal returns $[\sigma$ $(\mathrm{CAR}-20,+20)]$ and applied the $\mathrm{t}$ test, in order to verify the significance of the returns $[\mathrm{t}$ (CAR-20, +20)]. Calculations of standard deviation and t test were based on the following formulas:

$$
\begin{aligned}
\sigma\left(\overline{C A A}_{-20,+20}\right) & =\sqrt{r \bullet \operatorname{var}(A R)} \\
t\left(\overline{C A A}_{-20,+20}\right) & =\frac{\overline{C A A}-20,+20}{\sigma\left(\overline{C A R}{ }_{-20,+20}\right)}
\end{aligned}
$$

\subsection{DEFINITION OF ANALYZED EVENTS}

The Group Opportunity was selected for its prominence in the media over the past 10 years. Another deciding factor in choosing this group was their active participation in the management of several large companies and securities traded on the Stock Exchange. The selected companies, listed in Table 1, although a minority stake in Opportunity Group, were run by the group based on a shareholders' agreement signed since its privatization, and were quoted in complaints voiced by the Brazilian press.

Table 1 - List of Companies Selected for the Study of Event

\begin{tabular}{|l|l|l|l|}
\hline COMPANY & ECONOMIC SECTOR & SHARE & TYPE \\
\hline Brasil Telecom S/A & Telecommunications & BRTO3 & common \\
\hline Brasil Telecom S/A & Telecommunications & BRTO4 & preferred \\
\hline Telemig Celular Participações S/A & Telecommunications Holding & TMCP3 & common \\
\hline Telemig Celular Participações S/A & Telecommunications Holding & TMCP4 & preferred \\
\hline Tele Norte Celular Participações S/A & Telecommunications Holding & TNCP3 & common \\
\hline Tele Norte Celular Participações S/A & Telecommunications Holding & TNCP4 & preferred \\
\hline Santos Brasil Participações S/A & Transport Holding & STBP11 & Depositary receipt \\
\hline
\end{tabular}


Table 2 lists the news published in the Brazilian press over the last ten years that are directly related to allegations of illegal acts committed by the Opportunity Group. The subjects were selected at the site of the newspaper Folha de São Paulo, since this newspaper was the top in following different subjects related to the corruption issue over a period of nine months to just the year 2004 (BERABA, 2004).

The share prices of selected companies and the Index of the Stock Exchange of São Paulo (IBOVESPA), the latter regarded as proxies of the market return, were obtained from the historical database on the website of the Bolsa de Valores de São Paulo. We selected the daily average prices of common and preferred shares of the companies analyzed in order to minimize possible distortions with this speculation, or the opening or the end of each session.

Table 2 - List of Events Selected for Study

\begin{tabular}{|c|c|c|c|c|c|}
\hline $\begin{array}{l}\text { ZERO } \\
\text { DATE }\end{array}$ & $\begin{array}{c}\text { EVENT } \\
\text { WINDOW }\end{array}$ & EVENT & HEADLINE & SUBJECT & $\begin{array}{l}\text { COMPANIES } \\
\text { INVOLVED }\end{array}$ \\
\hline $24 / 04 / 2003$ & $\begin{array}{c}25 / 03 / 2003 \\
\text { to } \\
23 / 05 / 2003\end{array}$ & 1 & $\begin{array}{c}\text { Opportunity propose to } \\
\text { PREVI change share } \\
\text { Brazil Telecom and } \\
\text { Telemar } \\
\end{array}$ & & $\begin{array}{c}\text { Telemig Celular, Tele } \\
\text { Norte Celular e Brasil } \\
\text { Telecom }\end{array}$ \\
\hline $08 / 10 / 2003$ & $\begin{array}{c}10 / 09 / 2003 \\
\text { to } \\
05 / 11 / 2003\end{array}$ & 2 & $\begin{array}{l}\text { Opportunity defrauded } \\
\text { shareholders, says PREVI }\end{array}$ & $\begin{array}{l}\text { Bank would have favored foreign } \\
\text { investors, said the President of BB } \\
\text { funding }\end{array}$ & $\begin{array}{c}\text { Telemig Celular, Tele } \\
\text { Norte Celular e Brasil } \\
\text { Telecom }\end{array}$ \\
\hline $22 / 07 / 2004$ & $\begin{array}{c}23 / 06 / 2004 \\
\text { to } \\
19 / 08 / 2004\end{array}$ & 3 & $\begin{array}{l}\text { Brazil Telecom says that } \\
\text { target is Italian }\end{array}$ & $\begin{array}{l}\text { President of the corporation, Carla } \\
\text { Cico, denies the international } \\
\text { company hired Kroll to spy on } \\
\text { members of the Lula government }\end{array}$ & Brasil Telecom \\
\hline $10 / 11 / 2004$ & $\begin{array}{c}11 / 10 / 2004 \\
\text { to } \\
09 / 12 / 2004\end{array}$ & 4 & $\begin{array}{l}\text { Citigroup intends to break } \\
\text { up Opportunity }\end{array}$ & $\begin{array}{l}\text { American group has no plans to } \\
\text { renew partnership in Brazil with the } \\
\text { bank owned by Daniel Dantas }\end{array}$ & $\begin{array}{c}\text { Telemig Celular, Tele } \\
\text { Norte Celular e Brasil } \\
\text { Telecom }\end{array}$ \\
\hline $12 / 03 / 2005$ & $\begin{array}{c}14 / 02 / 2005 \\
\text { to } \\
12 / 04 / 2005\end{array}$ & 5 & $\begin{array}{l}\text { Agreement allows Dantas } \\
\text { stay with the telcos }\end{array}$ & $\begin{array}{c}\text { Entrepreneur has settled with } \\
\text { shareholders that allows him to be } \\
\text { ahead of Brasil Telecom until 2018, } \\
\text { Citigroup never approved }\end{array}$ & $\begin{array}{c}\text { Telemig Celular, Tele } \\
\text { Norte Celular e Brasil } \\
\text { Telecom }\end{array}$ \\
\hline $18 / 09 / 2005$ & $\begin{array}{c}19 / 08 / 2005 \\
\text { to } \\
18 / 10 / 2005\end{array}$ & 6 & $\begin{array}{l}\text { Letters indicate that } \\
\text { Palocci participated in } \\
\text { funding decisions }\end{array}$ & & $\begin{array}{l}\text { Telemig Celular, Tele } \\
\text { Norte Celular, Brasil } \\
\text { Telecom e Sanepar }\end{array}$ \\
\hline $13 / 12 / 2005$ & $\begin{array}{c}11 / 11 / 2005 \\
\text { to } \\
10 / 01 / 2006\end{array}$ & 7 & $\begin{array}{l}\text { BrT charges in court } \\
\text { Opportunity losses }\end{array}$ & $\begin{array}{l}\text { Tele calculates that the management } \\
\text { of Daniel Dantas has caused loss of } \\
\text { R \$362 million with "irregular" } \\
\text { operations }\end{array}$ & $\begin{array}{c}\text { Telemig Celular, Tele } \\
\text { Norte Celular e Brasil } \\
\text { Telecom }\end{array}$ \\
\hline $14 / 05 / 2006$ & $\begin{array}{c}12 / 04 / 2006 \\
\text { to } \\
12 / 06 / 2006\end{array}$ & 8 & $\begin{array}{l}\text { Government will process } \\
\text { Dantas, says Tarso }\end{array}$ & $\begin{array}{l}\text { President Auxiliary suggested that } \\
\text { the owner of the Opportunity wants } \\
\text { to "blackmail" the government; } \\
\text { cited deny having accounts abroad }\end{array}$ & Brasil Telecom \\
\hline $14 / 05 / 2006$ & $\begin{array}{c}12 / 04 / 2006 \\
\text { to } \\
12 / 06 / 2006 \\
\end{array}$ & 8 & $\begin{array}{l}\text { Tele hired people } \\
\text { connected to the PT }\end{array}$ & & $\begin{array}{c}\text { Telemig Celular, Tele } \\
\text { Norte Celular e Brasil } \\
\text { Telecom } \\
\end{array}$ \\
\hline $25 / 09 / 2006$ & $\begin{array}{c}25 / 08 / 2006 \\
\text { to } \\
24 / 10 / 2006 \\
\end{array}$ & 9 & $\begin{array}{c}\text { New evidence in the case } \\
\text { Telecom Italia should } \\
\text { affect BrT }\end{array}$ & & Brasil Telecom \\
\hline $30 / 11 / 2008$ & $\begin{array}{c}31 / 10 / 2008 \\
\text { to } \\
02 / 01 / 2009\end{array}$ & 10 & $\begin{array}{l}\text { Dantas laundered money in } \\
\text { the port of Santos, PF } \\
\text { accuses }\end{array}$ & $\begin{array}{c}\text { For police, banker bought } \\
\text { debentures from Santos Brazil with } \\
\text { funds from abroad }\end{array}$ & Santos Brasil S/A \\
\hline
\end{tabular}

The daily rates are based on the suggestion of Brown and Warner (1980) to argue that the power of event studies to increase knowledge about the accuracy of when an event occurred. Analyses were performed separately for assets, common and preferred shares, since 
the preferred shares have higher liquidity in the Brazilian capital market and therefore may have different performance in the sessions (CAMARGOS; BARBOSA, 2006, p. 49).

The company Santos Brazil has unit price, ie, its assets are composed of more than one class of securities which are traded together. Therefore, their prices figured in the calculations of the preferred shares and, since each unit represents one common share traded four preferred shares.

From a total of 26 events (news) relevant, 10 events met the requirements of the research, as shown in Table 2. Purged of the 16 events, 10 occurred on dates close and could affect the results of calculations of the coefficients alpha and beta. The remaining six events occurred in the periods in which certain assets were no longer in stock prices or were grouped as mentioned above. As the 10 selected events involving actions of more than one group, the final sample was composed of 28 series of quotes.

\section{RESULTS}

Table 3 shows the results of analysis of common and preferred shares of 28 series observed from 4 different companies.

Table 3 - Estimation of Beta Coefficients of Sample Common and Preferred Shares

\begin{tabular}{|c|c|c|c|c|c|c|c|}
\hline Company & Event & Beta & $\begin{array}{c}\text { Adjusted } \\
\mathbf{R}^{2}\end{array}$ & Sig. & Beta & $\begin{array}{c}\text { Adjusted } \\
\mathbf{R}^{2}\end{array}$ & Sig. \\
\hline & & \multicolumn{3}{|c|}{ Common share } & \multicolumn{3}{|c|}{ Preferred share } \\
\hline Brasil Telecom & 2 & 0.71994 & 0.281 & 0.000 & 0.69969 & 0.303 & 0.000 \\
\hline Brasil Telecom & 3 & 0.31374 & 0.045 & 0.024 & 0.64382 & 0.330 & 0.000 \\
\hline Brasil Telecom & 6 & 0.60740 & 0.068 & 0.007 & 0.66923 & 0.198 & 0.000 \\
\hline Brasil Telecom & 7 & 0.31512 & 0.012 & 0.149 & 0.50991 & 0.117 & 0.001 \\
\hline Brasil Telecom & 8 & 0.88042 & 0.117 & 0.001 & 0.51101 & 0.077 & 0.004 \\
\hline Brasil Telecom & 9 & 0.74256 & 0.074 & 0.005 & 0.62316 & 0.281 & 0.000 \\
\hline Telemig Celular Part. & 1 & 0.60357 & 0.174 & 0.000 & 0.80099 & 0.262 & 0.000 \\
\hline Telemig Celular Part. & 2 & 0.55169 & 0.094 & 0.002 & 0.62876 & 0.245 & 0.000 \\
\hline Telemig Celular Part. & 6 & 0.17977 & 0.016 & 0.123 & 0.68626 & 0.242 & 0.000 \\
\hline Telemig Celular Part. & 7 & 0.09718 & -0.006 & 0.500 & 0.58352 & 0.301 & 0.000 \\
\hline Telemig Celular Part. & 8 & 0.17062 & 0.001 & 0.302 & 0.47711 & 0.074 & 0.005 \\
\hline Telemig Celular Part. & 9 & 0.33179 & 0.055 & 0.014 & 0.57795 & 0.190 & 0.000 \\
\hline Tele Norte Celular Part. & 1 & 0.65612 & 0.174 & 0.000 & 0.31679 & 0.031 & 0.051 \\
\hline Tele Norte Celular Part. & 2 & 0.71917 & 0.103 & 0.001 & 0.47633 & 0.120 & 0.000 \\
\hline Tele Norte Celular Part. & 3 & 0.23422 & 0.019 & 0.101 & 0.28791 & 0.101 & 0.001 \\
\hline Tele Norte Celular Part. & 4 & -0.0113 & -0.011 & 0.953 & 0.04498 & -0.009 & 0.651 \\
\hline Tele Norte Celular Part. & 5 & 0.06747 & -0.010 & 0.753 & 0.60862 & 0.089 & 0.002 \\
\hline Tele Norte Celular Part. & 6 & 0.09520 & -0.009 & 0.647 & 0.39876 & 0.085 & 0.003 \\
\hline Tele Norte Celular Part. & 7 & -0.163 & -0.006 & 0.510 & 0.58622 & 0.167 & 0.000 \\
\hline
\end{tabular}


We can see that most of the common and preferred stock has beta coefficient lower than 1.0. That is, despite constant allegations of corruption involving the Group Opportunity and its' companies managed and studied here, the market understands that they are securities with lower risk relative to market risk. It was further observed that, in most cases, the beta coefficients of the preferred shares are larger than the betas calculated for the common shares, indicating a higher risk.

In Table 4 we present the results of the $t$ statistic for the event windows of common and preferred shares. When analyzing the average abnormal returns in Table 4, there are no significant abnormal returns in both the preferred and common shares. However, negative average abnormal returns were identified in two samples between day $t_{-2}$ and $t_{-1}$.

Table 4 - Estimation of Abnormal Returns and Cumulative Common Stock and Preferred

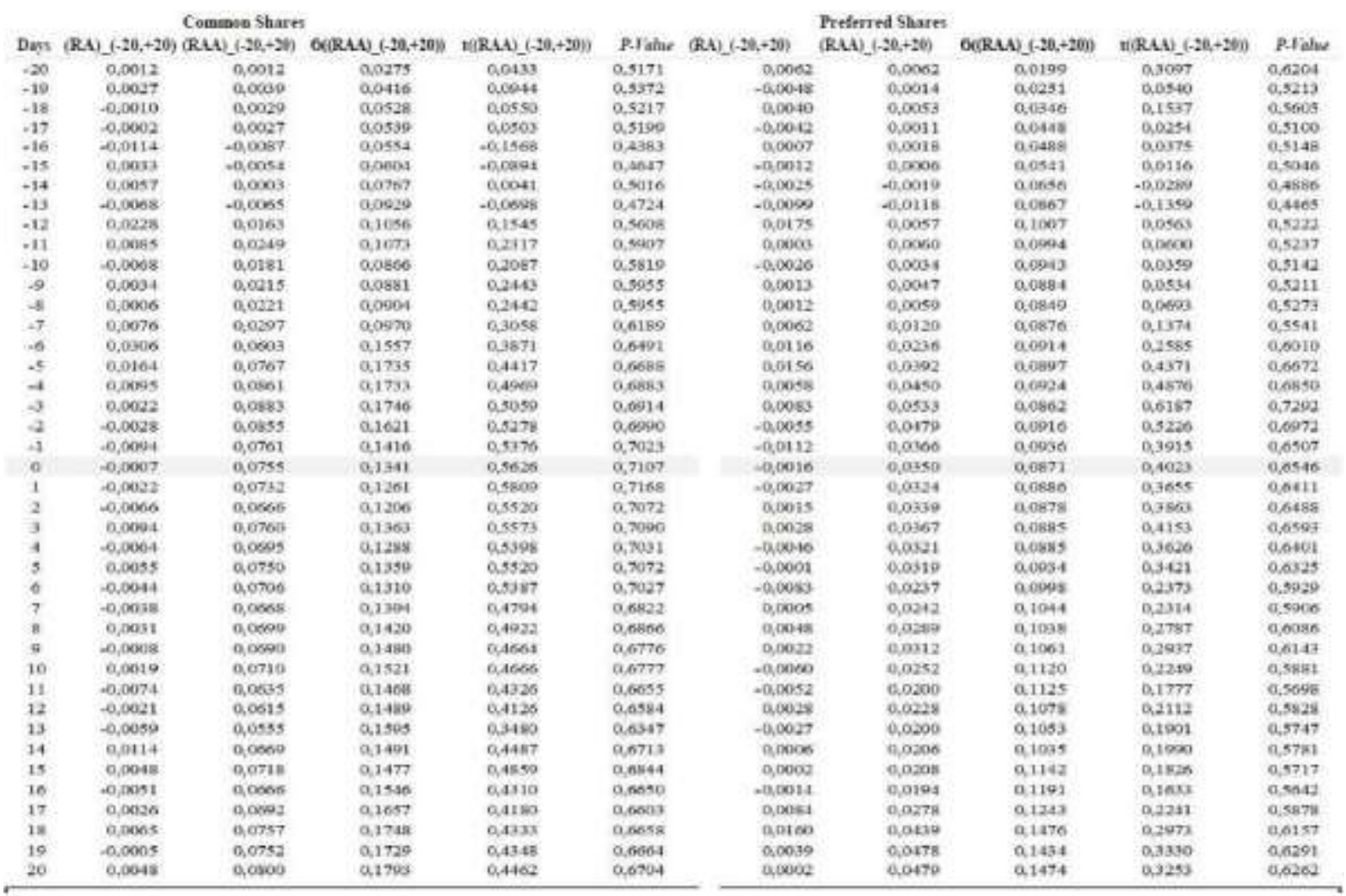

A abnormal return AA cumulative abnormal return $\sigma(\mathrm{AA})$ cumulative abnormal return standard error $\mathrm{t}(\mathrm{AA}) \mathrm{t}$ statistic

This fact indicates that the market reacted negatively next to the dissemination of relevant information into allegations of corruption in the period, but the negative effect on the share price during the period was not statistically significant. It is further understood that after the date $t_{0}$ there were abnormal returns alternating positive and negative, though not returned to higher levels checked the next day t-6. It can be assumed that investors have continued to 
operate with these assets in the market, but the results remained at levels below those seen before the zero date.

Figure 1 below, based on the average abnormal returns behavior, shows a similar performance of common and preferred shares in the event window. It may be noted that there is a greater dispersion of abnormal returns in the period between the day $\mathrm{t}_{-13}$ and $\mathrm{t}_{-1}$, which can be an indication that the news published in the zero date was already known in the market before its release at $t_{0}$. The day $t_{-1}$ represents one of the lowest abnormal returns of the period, though statistically not significant, according to the results presented in Figures 1 and 2 below.

Note also that after the announcement of the event (time zero) the occurrence of negative abnormal average became more frequent, but with less dispersion in relation to the days prior to advertising the event.

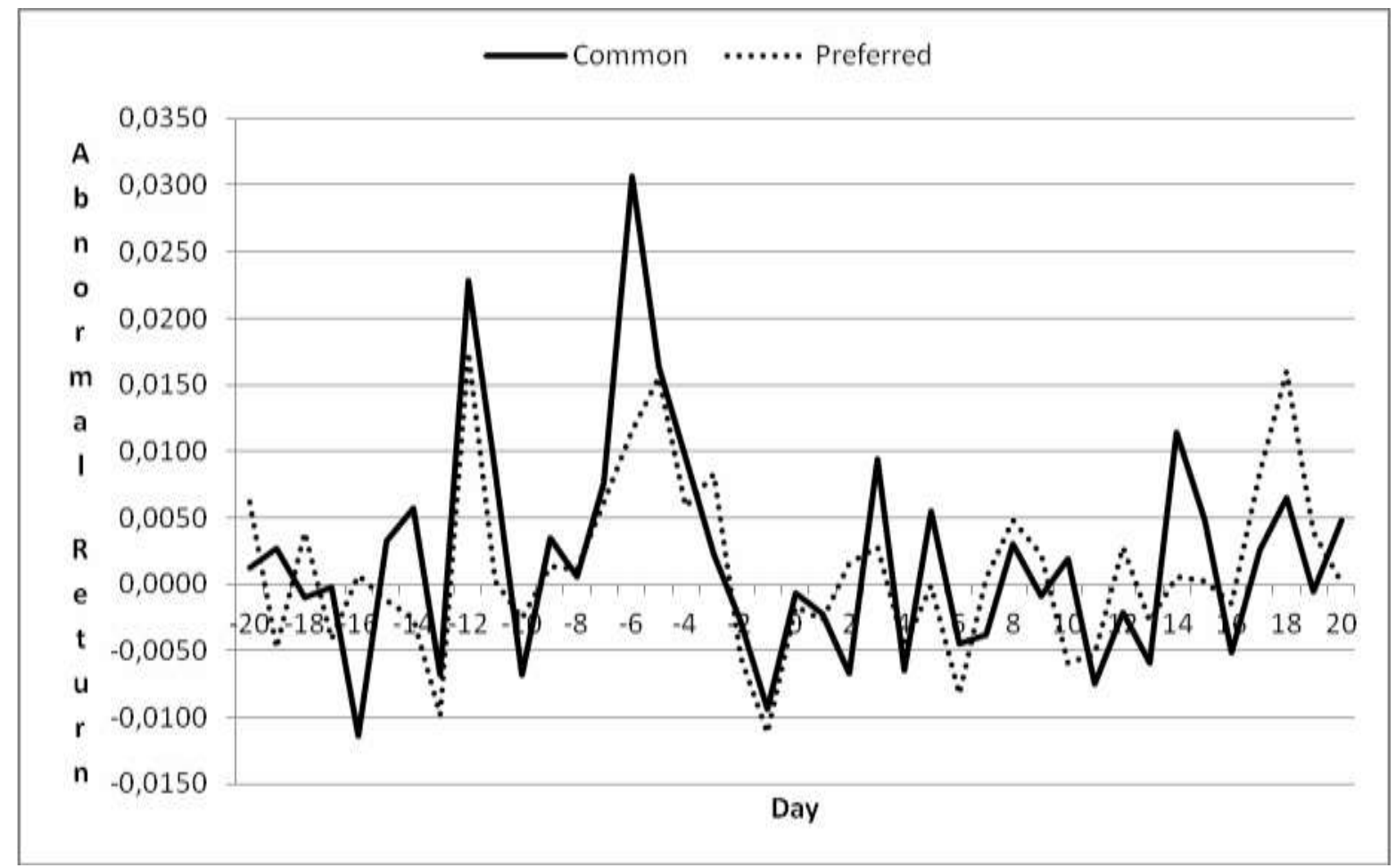

Figure 1 - Abnormal returns behavior in the event window $(-20$ to +20$)$. 


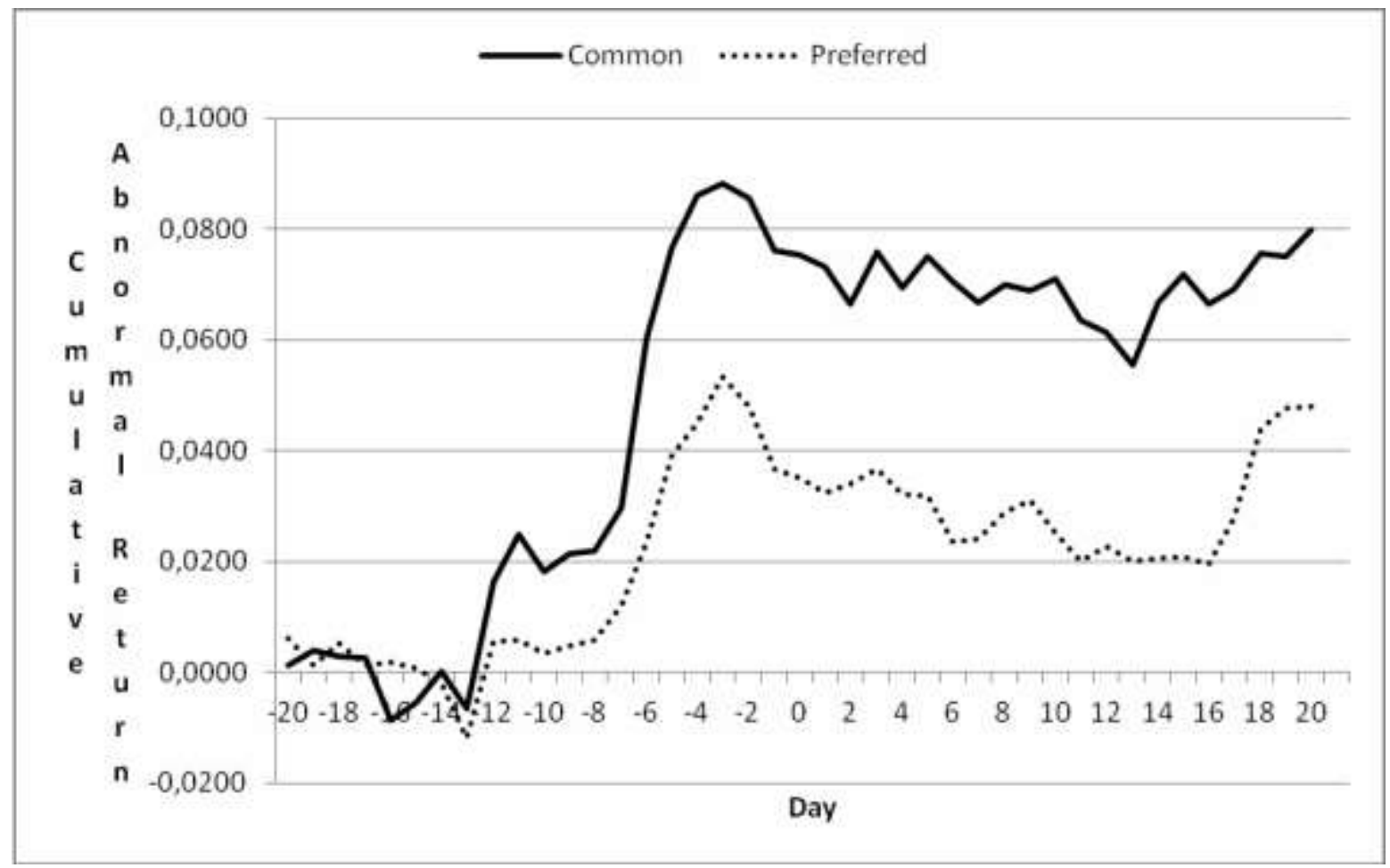

Figure 2 - cumulative abnormal returns in the event window $(-20$ to +20$)$.

It is worth noting that the average abnormal returns of the preferred shares fluctuated less than the average abnormal returns of the common shares. There were no abnormal returns averages higher than $0.02 \%$ for the preferred shares within the event window. This can be justified by the market liquidity of these shares in relation to common shares, allowing price adjustments less abrupt and more evenly distributed over time.

Figure 2 shows the cumulative abnormal results within the event window. The results presented indicate that, again, on day $\mathrm{t}_{-1}$ returns show steepest decline, which may be evidence that the market reacted negatively to the publication the day before the event. The same effect was observed in the study of Davidson III and Worrell (1988) in relation to day $\mathrm{t}_{-1}$. The authors explain the most significant negative $t_{-1}$ based on the following:

The reaction of days -1 is consistent with the concept of market efficiency (FAMA, 1976). Through the media and news services, analysts can obtain information about corporate misconduct and adjust their portfolios and recommendations before the announcement by the Wall Street Journal (DAVIDSON; WORRELL III, 1988, p. 198-199).

Finally, based on analysis of the average cumulative abnormal returns presented in Tables 1 and 2, considering a significance level of 5\% (p-value <0.05) and 10\% (p-value $<0.10)$ were not found statistically significant abnormal results in both the common shares as preferred shares. Abnormal positive earnings (CAA) are verified in Tables 1 and 2, however slight. The hypothesis is that the market did not consider allegations of corruption as relevant 
and not made, therefore, the adjustment of stock prices as one would expect, based on the efficient markets hypothesis.

\section{FINAL REMARKS}

With the present research, we sought to assess if the disclosure by media of corrupt acts committed by firms would lead to changes in shareholder value, through an event study covering four companies and 10 reported acts of corruption, totaling 28 events. The corrupt acts here analyzed indicate that companies would be classified as OC's, as taxonomy proposed by Pinto et al (2008), i.e., one in which members practice corrupt acts on behalf of the organization.

Moreover, noting those involved in allegations of unlawful acts, some in positions of high hierarchical rank, it confirms the propositions of Ermann and Lundman (2002), when they say the misconduct are addressed, whether directly or indirectly, by the organizational elites.

The results showed that the Brazilian stock market does not react efficiently when it comes to issues of organizational corruption. According to Davidson III and Worrell (1988), if the market operates efficiently, market forces could constrain the "errant behavior of the administration" of corporations, from the reports circulated.

The research findings reinforce the suggestions of Anand, Ashforth and Joshi (2005) about the tendency to become acceptable and constant the practice of corrupt acts in organizations. According to the authors, individuals draw mental strategies to make their corrupt acts justified for themselves and those around them. Therefore, it is not surprising that the market behavior does not punish the illegal acts, since they tend to provide advantages for the organization and hence to its shareholders.

However, if the market does not operate efficiently, the Government must provide the necessary regulation to prevent corrupt behavior of organizations, which confirms the propositions of Miranda and Simioni (2005) on the need for modernization of the Brazilian legislation, even if only it cannot guarantee the extinction of corrupt acts in the business activities of the country, both public and private.

As limitations of this study we can highlight the type of events examined (allegations of crimes commented by a specific business group), resulting in a small number of selected companies ( 4 companies run by Opportunity Group) and a small sample (28 events). Thus, studies that addressed a greater number of events could come to meet this limitation. 
However, this study represents another step in research on corporate social responsibility, which are usually examined by means of subjective indices of social responsibility and improper accounting measures of financial performance.

It is worth mentioning that the research does not address the types of crimes. It is known that some corporate crimes are inherently bad, but others affect the general population, for example, environmental pollution (DAVIDISON III; WORRELL, 1988). Therefore, future studies can address the effects for shareholders by type of crime, aiming to measure whether the type of crime committed by a particular organization can be positive or negative effect of the stock value of companies.

\section{REFERENCES}

ADVERSE, H. M. In. AVRITZER, L. et al. (Orgs.). Corrupção: ensaios e críticas. Belo Horizonte: Editora UFMG, 2008.

AIDT, T. S. Economic analysis of corruption: a survey. Economic Journal, p 632-652. 2003.

ANAND, V.; ASHFORTH, B. E.; JOSHI M. Business as usual: the acceptance and perpetuation of corruption in organization. Academy of Management Executive, v. 19, n. 4, p. 9-23, 2005.

ASHFORTH, B. E.; ANAND, V. The normalization of corruption. Research in Organizational Behavior, v. 25, p. 1-52, 2003.

AVRITZER, L. et al. (Orgs.). Corrupção: ensaios e críticas. Belo Horizonte: UFMG, 2008. $598 \mathrm{p}$.

BERABA, M. Imprensa e corrupção. Folha de S. Paulo, nov. 29, 2010. Disponível em: <http:www1.folha.uol.com.br/fsp/ombudsman/om1212200402.htm>.

BONOMI, C. A.; MALVESSI, O. Project finance no Brasil: fundamentos e estudos de casos. São Paulo: Atlas, 363 p. 2002.

BORINI, F. M.; GRISI, F. C. Estratégia e corrupção. In: ENCONTRO NACIONAL DA ASSOCIAÇÃO DOS PROGRAMAS DE PÓS-GRADUAÇÃO EM ADMINISTRAÇÃO (ENANPAD), 31., 2007, Rio de Janeiro (RJ). Anais... Rio de Janeiro: ANPAD, 2007.

BM\&FBOVESPA. Cotações históricas das ações. São Paulo, 2005. Disponível em: <http://www.bmfbovespa.com.br/shared/iframe.aspx?idioma=ptbrandurl=http://www.bmfbov espa.com.br/pt-br/cotacoes-historicas/FormSeriesHistoricas.asp>. Acesso em: 05 jun. 2009.

CAMARGOS M. A.; BARBOSA, F. V. Teoria e evidência da eficiência informacional do mercado de capitais brasileiro. Caderno de Pesquisas em Administração, São Paulo, v. 10, n. 1, p. 41-55. 2003.

Estudo de evento: teoria e operacionalização. Caderno de Pesquisas em

Administração, São Paulo, v. 10, n. 3, pp. 1-20. 2003, setembro. 
Eficiência informacional do mercado de capitais brasileiro pós-Plano Real: um estudo de eventos dos anúncios de fusões e aquisições. Caderno de Pesquisas em Administração, São Paulo, v. 41, n. 1, pp. 43-58. 2006, março.

COLLIS, J.; HUSSEY, R. Pesquisa em administração. Porto Alegre: Bookman. 2005.

COMPARATO, F. K. Ética: direito, moral e religião no mundo moderno. São Paulo: Companhia das Letras, 2006. 716 p.

CRICK, B. Democracy: a very short introduction. Oxford University Press. 2002.

CRUZ, E. P. MPF denuncia Dantas e aponta ligação do Opportunity com valerioduto. Agência Brasil - EBC Empresa Brasil de Comunicação, Brasília, 2009. Disponível em: <http://www.agenciabrasil.gov.br/noticias/2009/07/06/materia.2009-0706.9348050543/view>. Acesso em: 29 jul. 2009.

DAMODARAN, A. Corporate finance: theory and practice. New York: Wiley, 1997. 876 p.

DAVIDSON III, W. N.; WORRELL, D. L. The impact of announcements of corporate illegalities on shareholder retorns. Academy of Manangement Journal, New York, v. 31, n. 1, p. 195-200, mar. 1988.

ERMANN, M. D.; LUNDMAN, R. J. Corporate and governmental deviance: problems in organizational behaviori in contemporany society. 6. ed. New York: Okford Univesity Press, 335 p. 2002.

FOLARIN, G. O. Lk 12:13-21 in the context of human corruption. Asia Journal of Theology, Serampore, v. 24, n. 2, p. 312-32, out. 2010.

GARCIA, F. G.; SATO, L. G.; CASELANI, C. N. O impacto da política de transparência sobre o valor das empresas brasileiras. In: ENCONTRO NACIONAL DA ASSOCIAÇÃO DOS PROGRAMAS DE PÓS-GRADUAÇÃO EM ADMINISTRAÇÃO (ENANPAD), 28., 2004, Curitiba (PR). Anais... Curitiba: ANPAD, 2004.

GITMAN, L. J. Princípios de administração financeira. 7. ed. São Paulo: Harbra, 1997. $841 \mathrm{p}$.

HAIR, JR. et al. Fundamentos de métodos de pesquisa em administração. Porto Alegre: Bookman, 2005.

HEIDENHEIMER, A. J. Perspectives on the perception of corruption. In: Political corruption: concepts and contexts. 3. ed. New Brunswick, 2002. Cap. 9, p. 141-154.

JAIN, A. K. Corruption: a review. Journal of Economic Surveys, v. 15, p. 71-121, 2001.

JONES, T. M. Ethical decision making by individuals in organizations: an issue-contingent model. Academy of Management Review, v. 16, p. 366-395, 1991.

KLITGAARD, R. Controlling corruption. Los Angeles: University of California Press, 1991. 
JENSEN, M. C.; MECKLING, W. H. Theory of the firm: managerial behavior, agency costs and ownership structure. Journal of Financial Economics, v. 3, n. 4, p. 305-360, out. 1976.

LIMA, V. A. Mídia. In. AVRITZER, L. et al. (Orgs.). Corrupção: ensaios e críticas. Belo Horizonte: Editora UFMG, 2008.

MANZ, C. C.; JOSHI, M.; ANAND, V. The role of values and emotions in newcomers' socialization into organizational corruption. In: ACADEMY OF MANAGEMENT ANNUAL MEETING, 2005, Honolulu (HAWAII). Anais... Honolulu: [s.n.], 2005. p. 1-6.

MARTINS, J. A. Corrupção. São Paulo: Globo, 2008. 129 p.

MAURO, P. Corruption and growth. The Quarterly Journal of Economics, [S. I.], p. 68171, ago. 1995.

MACKINLAY, A. C. Event studies in economics and finance. Journal of Economic Literature, v. 35, p. 13-39, mar. 1997.

MIRANDA, D.; SIMIONI, R. L. Direito, silêncio e corrupção: um diálogo com Niklas Luhmann e Jürgen Habermas. Jus Navigandi, 2005. Disponível em:

<http://jus2.uol.com.br/doutrina/texto.asp?id=9797andp=1>. Acesso em: 23 jun. 2009.

MISANGYI, V. F.; WEAVER, G. R.; ELMS, H. Ending corruption: the interplay among institutional logics, resources, and institutional entrepreneurs. Academy of Manangement Review, v. 33, n. 3, p. 750-770, jul. 2008.

MOTA, H. M. V.; OLIVEIRA, V. I. Economic value added (EVA) e cash value added (CVA): uma análise comparativa. In: ENCONTRO NACIONAL DA ASSOCIAÇÃO DOS PROGRAMAS DE PÓS-GRADUAÇÃO EM ADMINISTRAÇÃO (ENANPAD), 28., 2004, Curitiba (PR). Anais... Curitiba: ANPAD, 2004.

NICE, D. C. The police consequences of political corruption. Political Behavior, v. 8, p. 287295, 1986.

NIELSEN, R. P. Corruption networks and implications for ethical corruption reform. Journal of Business Ethics, v. 42, p. 125-149, 2003.

PARDINI, D. J.; MACHADO, D. C.; COSTA Y. Organizational corruption: practices and anti-corruption controls in Brazilian banks. In: European Group of Organization Studies (EGOS), 29., 2013, Montreal (CAN). Anais... Montreal: EGOS, 2013.

PARDINI, D. J. et al. Práticas de corrupção e mecanismos de controle e prevenção em bancos brasileiros: um estudo sob a perspectiva de gerentes e funcionários. In: ENCONTRO NACIONAL DA ASSOCIAÇÃO DOS PROGRAMAS DE PÓS-GRADUAÇÃO EM ADMINISTRAÇÃO (ENANPAD), 35., 2011, Rio de Janeiro (RJ). Anais... Rio de Janeiro: ANPAD, 2011.

PEREIRA, S. B.; EID JUNIOR, W. Medidas de criação de valor e o retorno das ações. In: ENCONTRO NACIONAL DA ASSOCIAÇÃO DOS PROGRAMAS DE PÓSGRADUAÇÃO EM ADMINISTRAÇÃO (ENANPAD), 26., 2002, Salvador (BA). Anais... Salvador: ANPAD, 2002. 
PINTO, J.; LEANA, C.; PIL, F. K. Corrupt organizations or organizational of corrupt individuals? Two types of organization-level corruption. Academy of Manangement Review, v. 33, n. 3, p. 685-709, 2008.

RAPPAPORT, A. Gerando valor para o acionista: um guia para administradores e investidores. São Paulo: Atlas, 2001. 219 p.

ROCCA, C. A. (Org.). Revolução no mercado de capitais do Brasil: o crescimento rescente é sustentável? Rio de Janeiro: Elsevier: IBMEC, 2008. 184 p.

ROSA, M. F. E. Corrupção como entrave ao desenvolvimento. Jus Navigandi, São Paulo, 2004. Disponível em: <http://jus2.uol.com.br/doutrina/texto.asp?id=4870>. Acesso em: 23 jun. 2009.

SANTANA, M. H. F. O novo mercado e a governança corporativa. Revista da CVM. Rio de Janeiro, n. 35, p. 4-8, abr. 2002.

SHLEIFER, A.; VISHNY, R. W. Corruption. Quarterly Journal of Economics, v. 108, p. 599-617, 1993.

SCHWARTZMAN, S. Coesão social, democracia e corrupção. São Paulo: iFHC/CIEPLAN, 2008. 37 p.

SOUSA, L. As agências anticorrupção como peças centrais de um sistema de integridade. Revista da CGU, Brasília, Controladoria-Geral da União, ano 3, n. 4, p. 20-45, jun. 2008.

ZINNBAUER, D. Ambient accountability fighting corruption where and when it happens. Draft working paper, out. 2012. 